\title{
Synthesis of Tetraaza Derivatives of Benzoxazinophenothiazine
}

\section{BENJAMIN E. EZEMA ${ }^{1 *}$, CHIDIMMA G. EZEMA ${ }^{2}$, JUDE I. AYOGU ${ }^{1}$, DAVID I. UGWU ${ }^{1}$ and EFETURI A. ONOABEDJE ${ }^{1}$}

\author{
'Department of Pure and Industrial Chemistry, \\ Faculty of Physical Sciences, University of Nigeria, Nsukka, Nigeria. \\ ${ }^{2}$ National Centre for Energy Research and Development, University of Nigeria, Nsukka, Nigeria. \\ ${ }^{*}$ Corresponding author E-mail: Benjamin.ezema@unn.edu.ng
}

(Received: December 06, 2014; Accepted: January 09, 2015)

http://dx.doi.org/10.13005/ojc/310114

\begin{abstract}
Tetraaza benzoxazinophenothiazine heterocyclic rings were synthesized and characterized. The key intermediate, 11-amino-6-chlorobenzo[a]-8,10-diazaphenoxazin-5-one was prepared by reaction of 4,5-diamino-6-hydroxypyimidine with 2,3-dichloro-1,4-naphthoquinone in anhydrous sodium carbonate. Whereas the parent tetraaza derivatives: 15-amino-8-bromo6,9,12,14-tetraazabenzo[a][1,4]benzoxazino[3,2-c] phenothiazine, 9,15-diamino-6,8,12,14tetraazabenzo[a][1,4]benzoxazino[3,2-c]pheno- thiazine and 15-amino-6,8,12,14tetraazabenzo[a][1,4]benzoxazino[3,2-c]phenothiazine were synthesized by base catalyzed condensation reactions of 11-amino-6-chlorobenzo[a]-8,10-diazaphenoxazin-5-one with 2-amino5-bromopyrazin-3-thiol, 4,6-diaminopyrimidine-5-thiol and 4-diaminopyrimidine-5-thiol respectively. The compounds are intensely coloured and are readily reduced with sodium dithionite to their leuco bases which can make them applicable as vat dyes. Their wash fastness, sublimation fastness and staining undyed fabric were evaluated.
\end{abstract}

Key words: 2-Amino-5-bromopyrazin-3-thiol; 4,5-diamino-6-hydroxypyimidine; 4,6-diaminopyrimidine-5-thiol; 2,3-dichloro-1,4-naphthoquinone; Leuco Base; Vat dye; alkaline hydrolysis; condensation reaction.

\section{INTRODUCTION}

The application of phenoxazine and phenothiazine compounds and their derivatives in drug, textile, agriculture and other related industries has long been recognized. Phenoxazine and its derivatives were found to show tremendous pharmacological activities as antiepileptic, sedatives, CNS depressants, tranquilizing agents, antitumor, ${ }^{1}$ antibacterial, anthelminthic, spasmolytic, anticancer ${ }^{2}$ and parasticidal agents. ${ }^{3}$ Other applications include their use as antioxidants and biological stains, ${ }^{4}$ laser dyes, ${ }^{5}$ acid-base indicators, bromometric and stannometric indicators ${ }^{6}$ and especially as chromophoric compound ${ }^{7}$ in host guest artificial protonic antenna system. 
However, phenothiazines and their derivatives are useful in medicine as antitussive and antitumor agents, anticonvulsants, tranquilizers, antipsychotics, antimalarial agents ${ }^{8}$ and in the treatment of prion disease ${ }^{9}$, to mention but a few. In textile, paint and plastic industries, they are used as vat dyes and pigments ${ }^{10}$; and in agricultural industries, as insecticides and nematodicides. ${ }^{11}$ In petroleum industries, they have<smiles></smiles>
1<smiles></smiles>

2 been found useful as antioxidants in lubricants and fuels. ${ }^{12}$

The three-branched fused phenothiazine ring of the type $1^{13}$ has been known for more than a century. The monoaza-, diaza- and triaza-analogues of benzoxazinophenothiazine rings of the types $\mathbf{2}$, $3,4{ }^{14}$ have been known. The authors wish to report here the successful synthesis of tetraaza-analogue.<smiles></smiles>

3



4

\section{EXPERIMENTAL}

The solvents were of analytical grade from Sigma-Aldrich. 2-aminopyrazine, 4,6diaminopyrimidine, 4,5-Diamino-6hydroxypyrimidine and 2,3-dichloro-1,4naphthoquinone were also products of Aldrich chemicals. Melting points were determined using electrothermal melting point apparatus in open capillaries and were uncorrected. The reactions were monitored with TLC and also the purity was ascertained with TLC. Infrared spectra were recorded on FT-IR 8400 S spectrophotometer using $\mathrm{KBr}$ discs. Nuclear magnetic resonance spectra $\left({ }^{1} \mathrm{H}-\right.$ NMR and ${ }^{13} \mathrm{C}$-NMR) were determined using Brucker $300 \mathrm{MHz}$ instrument; chemical shifts were reported on (ppm) scale.

Elemental analysis was obtained on Heraous rapid analyzer

2-Amino-5-bromopyrazin-3-thiol (8)

Procedure as reported in literature. ${ }^{15}$

A mixture of 2-amino-3,5-dibromopyrazine 6 (10 g, 42 mmole) and sodium hydrosulphide (4.86 $\mathrm{g}, 84 \mathrm{mmole}$ ) was poured in a $250 \mathrm{~mL}$ reaction flask attached to reflux condenser. Methanol $(100 \mathrm{~mL})$ was added and the mixture was refluxed for $13 \mathrm{~h}$ in water bath. A little amount of activated carbon was added and the mixture boiled for additional $15 \mathrm{~min}$. It was then filtered and the filtrate was allowed to cool. It was neutralized with dilute hydrochloric acid to give dirty brown precipitates which was filtered and dried in a desiccator. Pure sample for analysis were further recrystallized from aqueous DMF. M.p. $>300^{\circ} \mathrm{C}$; FT-IR $(\mathrm{KBr}): v_{\text {max }} 3488,3420\left(\mathrm{NH}_{2}\right), 1589$ $(\mathrm{C}=\mathrm{C}, \mathrm{C}=\mathrm{N}), 770$ and $728 \mathrm{~cm}^{-1}$.

\section{4,6-Diamino-5-thiocyanatopyrimidine (10)}

4,6-Diaminopyrimidine 9 (15.00 g, 14 $\mathrm{mmol}$ ) was poured into a litre of three-necked flask equipped with a reflux condenser, mechanical glass stirrer and dropping funnel. Glacial acetic acid cooled to $18{ }^{\circ} \mathrm{C}$ was added and the mixture was further cooled in an ice-salt bath. Sodium thiocyanate $(22.00 \mathrm{~g})$ was added with stirring while maintaining the temperature at $-5{ }^{\circ} \mathrm{C}$ and $0{ }^{\circ} \mathrm{C}$. Bromine $(8.00 \mathrm{~mL})$ was added in droplets from the dropping funnel to the ice cooled mixture for over 1 $\mathrm{h}$ and stirring was continued for a period of $5 \mathrm{~h}$ while maintaining the temperature near $0{ }^{\circ} \mathrm{C}$. The slurry was left overnight, water was added and mixture warmed to $80^{\circ} \mathrm{C}$ and filtered hot. The filtrate was preserved and the orange residue extracted with acetic acid. The acetic acid extract was combined with the preserved filtrate and neutralized with concentrated ammonia while cooling and maintaining the temperature below $30^{\circ} \mathrm{C}$. It was then filtered and the residue recrystallized from methanol to give 4,6-diamino-5-thiocyanatopyrimidine as bright yellow solid, m.p.181-182 ${ }^{\circ} \mathrm{C}$ (lit. 183-184 ${ }^{\circ} \mathrm{C}$ ) [15]; FT-IR (KBr): v max 3475, $3415\left(\mathrm{NH}_{2}\right), 1579$ $(\mathrm{C}=\mathrm{C}, \mathrm{C}=\mathrm{N}), 1160,790$ and $730 \mathrm{~cm}^{-1}$. 


\section{4, 6-Diaminopyrimidine-5-thiol (11)}

4,6-Diamino-5-thiocyanatopyrimidine 10 $(12.00 \mathrm{~g}, 72 \mathrm{mmol})$ was added into a reaction flask containing potassium hydroxide $(40 \mathrm{~g})$ water (100 $\mathrm{mL})$. The mixture was refluxed in sand bath for $13 \mathrm{~h}$ until ammonia gas ceased to evolve. Activated carbon was added to the mixture and it was refluxed for further $20 \mathrm{~min}$, it was filtered hot and the filtrate allowed cooling. It was neutralized with glacial acetic acid in ice-salt bath while maintaining the temperature below $10{ }^{\circ} \mathrm{C}$. It was filtered and the residue recrystallized from methanol to give 4,6Diaminopyrimidine-5-thiol (11) as yellow crystals. FT-IR (KBr): $v_{\text {max }} 3480,3413\left(\mathrm{NH}_{2}\right), 1590(\mathrm{C}=\mathrm{C}$, $\mathrm{C}=\mathrm{N}), 1140,1080780$ and $735 \mathrm{~cm}^{-1}$.

11 - A m i n o- 6 - c h l o r o b e nzo [a ] - 8, 10 diazaphenoxazin-5-one (14)

4,5-Diamino-6-hydroxypyrimidine 12 (2.0 $\mathrm{g}, 15 \mathrm{mmol}$ ) and anhydrous sodium carbonate (2.5 $\mathrm{g}, 23 \mathrm{mmol}$ ) were poured in a three-necked reaction flask $(250 \mathrm{~mL})$. A solution of benzene $(120 \mathrm{~mL})$ and DMF $(15 \mathrm{~mL})$ was added and the mixture was boiled for 45 min until complete dissolution. 2,3-Dichloro1,4-naphthoquinone 13 (3.60 g, $15 \mathrm{mmol}$ ) was later added and the mixture refluxed for $5 \mathrm{~h}$ in water bath at $75-80{ }^{\circ} \mathrm{C}$. At the end of the reflux period, benzene was distilled off and the slurry poured into water $(100 \mathrm{~mL})$ and stirred to dissolve the inorganic material. It was cooled overnight, filtered and the residue was recrystallized from acetone after treatment with activated carbon to give 11-amino6-chlorobenzo[a]-8,10-diazaphenoxazin-5-one 14 as deep orange powder; m.p. 290-291 ${ }^{\circ} \mathrm{C}$. FT-IR $(\mathrm{KBr}): v_{\max } 3470,3339 \mathrm{~cm}-1,\left(\mathrm{NH}_{2}\right), 1655(\mathrm{C}=\mathrm{O})$, 1589, $1540(\mathrm{C}=\mathrm{C}, \mathrm{C}=\mathrm{N}) .{ }^{1} \mathrm{H}-\mathrm{NMR}$ (DMSO) ppm: 7.80-7.70 (5H, m, Ar-H), $6.90\left(\mathrm{~s}, \mathrm{NH}_{2}\right) .{ }^{13} \mathrm{C}-\mathrm{NMR}$ $\left(\mathrm{CDCl}_{3}\right)$ ppm: $191.3(\mathrm{C}=\mathrm{O}), 168.7,165.8,161.3$, $150.3,148.3$, 137.5, 134.1, 133.0, 131.2, 129.9, 137.8, 126.9, 116.5 .

Analysis: Calculated for $\mathrm{C}_{14} \mathrm{H}_{7} \mathrm{~N}_{4} \mathrm{ClO}_{2}$ : (\%): C, 56.30; H, 2.36; N, 18.76; Cl, 11.87 .

Found: C, 56.32; H, 2.36; N, 18.74; Cl, 11.89.

\section{General Procedure for the Preparations of the Complex Compounds}

2-Amino-5-bromopyrazin-3-thiol 8 (2.0 g, $97 \mathrm{mmol}$ ) and anhydrous sodium carbonate $(1.0 \mathrm{~g}$, $97 \mathrm{mmol}$ ) were poured in 3-necked reaction flask
(250 mL) containing a solution of benzene (100 $\mathrm{mL})$ and DMF $(20 \mathrm{~mL})$. The mixture was warmed in a water bath for $45 \mathrm{~min}$ until complete dissolution. 11 - A m i no - 6 - c h l o r o be n zo [ a ] - 8, 10 diazaphenoxazin-5-one $14(2.89 \mathrm{~g}, 97 \mathrm{mmol})$ was later added and the entire mixture was refluxed in a water bath with continuous stirring for $11 \mathrm{~h}$. Benzene was distilled off and the slurry was poured into water $(600 \mathrm{~mL})$ and warmed to dissolve the inorganic material. It was filtered, washed with water, recrystallized from aqueous acetone and later treated with activated charcoal to yield $\mathbf{1 8}$ as intense red powder. M. p. $>320^{\circ}$ (dec.); IR (KBr): $v_{\max } \mathrm{cm}^{-1} 3466,3396\left(\mathrm{NH}_{2}\right), 1598,1472(\mathrm{C}=\mathrm{N}, \mathrm{C}=\mathrm{C})$. ${ }^{1} \mathrm{H}-\mathrm{NMR}$ (DMSO) ppm: $9.10(\mathrm{H}-7, \mathrm{~s}), 7.85-7.70(\mathrm{~m}$, $\mathrm{H} 1, \mathrm{H} 2, \mathrm{H} 3, \mathrm{H} 4), 6.90\left(\mathrm{br}, \mathrm{NH}_{2}\right) ;{ }^{13} \mathrm{C}-\mathrm{NMR}\left(\mathrm{CDCl}_{3}\right)$ ppm: 157.7, 153.0, 151.5, 148.1, 147.1, 145.8, $139.2,137.6,136.0,134.4,132.2,130.6,130.0$, 119.5 .

Analysis: Calculated for $\mathrm{C}_{18} \mathrm{H}_{8} \mathrm{~N}_{7} \mathrm{OSBr}$ : (\%): $\mathrm{C}, 48.01, \mathrm{H}, 1.79, \mathrm{~N}, 21.77, \mathrm{~S}, 7.12, \mathrm{Br}, 17.75$. Found: C, 48.05, H, 1.77, N, 21.77, S, 7.12, Br, 17.76.

9,15-Diamino-6,8,12,14-tetraazabenzo[a][1,4] benzoxazino[3,2-c]phenothiazine (22)

4,6-Diaminopyrimidine-5-thiol 11 (2.0 g, $14 \mathrm{mmol})$ was condensed with 11-Amino-6-chlorobenzo[a]8,10-diazaphenoxazin-5-one 14 (4.20 g, 15 mmol) in presence of anhydrous sodium carbonate (1.67 $\mathrm{g}, 15 \mathrm{mmol})$ to give 9,15-diamino-6,8,12,14tetraazabenzo[a][1,4]benzoxazino[3,2c]phenothiazine as reddish brown powder. $\mathrm{mp}>$ $300^{\circ}$ (dec.); FT-IR (KBr): $v_{\max } \mathrm{cm}^{-1} 3450,3376\left(2 \mathrm{NH}_{2}\right)$, 1590, 1482 (C=N, C=C); ${ }^{1} \mathrm{H}-\mathrm{NMR}$ (DMSO) ppm: 8.35 (1H, s, H-7), 7.90-7.75 (m, H1, H2, H3, H4) and $6.91\left(2 \mathrm{NH}_{2}, \mathrm{~s}\right),{ }^{13} \mathrm{C}-\mathrm{NMR}\left(\mathrm{CDCl}_{3}\right) \mathrm{ppm}: 159.7,157.0$, $155.5,152.1,147.1,138.8,135.2,126.6,123.0$, $121.4,120.2,119.6,119.0,118.7$.

Analysis: Calculated for $\mathrm{C}_{18} \mathrm{H}_{10} \mathrm{~N}_{8} \mathrm{OS}$ : (\%): C, 55.95, H, 2.61, N, 29.00, S, 8.30, Found: C, 55.97, H, 2.59, N, 29.03, S, 8.29.

15- A mino-6, 8, 12, 14-tetraazabenzo[a] $[1,4]$ benzoxazino[3,2-c]phenothiazine (22)

4-Aminopyrimidine-5-thiol 11 (2.0 g, 15 mmol) condensed with 11-Amino-6chlorobenzo[a]-8,10-diazaphenoxazin-5-one 14 $(4.69 \mathrm{~g}, 15 \mathrm{mmol})$ in the presence of anhydrous 
sodium carbonate $(1.67 \mathrm{~g}, 15 \mathrm{mmol})$ to give 15 a mino- $6,8,12,14$ - tet ra azabenzo[a] $[1,4]$ benzoxazino[3,2-c]phenothiazine as dark purple brown powder $\mathrm{mp}>320^{\circ}$ (dec.). $\mathrm{FT}-\mathrm{IR}(\mathrm{KBr})$ : $v_{\max } \mathrm{cm}^{-1} 3450,3376\left(\mathrm{NH}_{2}\right), 1598,1472(\mathrm{C}=\mathrm{N}, \mathrm{C}=\mathrm{C})$.

${ }^{1} \mathrm{H}-\mathrm{NMR}$ (DMSO) ppm: 8.70 (s, H-7), 8.55 (s, $\mathrm{H}-9), 7.8-7.75(\mathrm{~m}, \mathrm{H} 1, \mathrm{H} 2, \mathrm{H} 3, \mathrm{H} 4)$ and $6.50\left(\mathrm{NH}_{2}\right.$, s), ${ }^{13} \mathrm{C}-\mathrm{NMR}\left(\mathrm{CDCl}_{3}\right)$ ppm: 159.7, 157.0, 155.5, 152.1, 147.1, 145.8, 143.2, 136.6, 133.0, 131.4, $130.2,129.6,129.0,119.7$

Analysis: Calculated for $\mathrm{C}_{18} \mathrm{H}_{10} \mathrm{~N}_{8} \mathrm{OS}$ : (\%): C, 58.22, H, 2.44, N, 26.40, S, 8.63,

Found: C, 58.27, H, 2.44, N, 26.38, S, 8.67.

\section{General Method of Dyeing with the Compounds 14,18 and 22}

The dye compounds $(0.20 \mathrm{~g})$ each were weighed into separate reaction flasks attached to reflux condensers and thermometers. Acetone (60 $\mathrm{mL}$ ) was added to the separate reaction mixtures each and warmed in water bath to achieve dissolution. Little volume of DMF $(5.0 \mathrm{~mL})$ was also added to aid complete dissolution. Sodium dithionite $(5.0 \mathrm{~g})$ was later added and the mixtures refluxed for $2 \mathrm{~h}$ and allowed to cool to $40^{\circ} \mathrm{C}$. Pieces of rayon fabrics were inserted into the separate solutions followed by addition of glacial acetic $(5.0 \mathrm{~mL})$. The mixtures were refluxed with gradual increase in temperature and occasional agitation for further 1 h. They were quickly cooled to room temperature and the fabrics were removed and air-dried. Their wash fastness, stain on undyed fabric and sublimation fastness based on the international geometric gray standard ( 1 for poor and 5 for excellent respectively) were ascertained.

\section{RESULTS AND DISCUSSION}

2-Aminopyrazine 5 was converted to 3,5dibromo-2-aminopyrazine 6 by treating with bromine in acetic acid and sodium acetate. Refluxing 6 in methanol and sodium hydrosulphide for $13 \mathrm{~h}$ gave the sodium salt 7 which was then neutralized with glacial acetic acid to give 2-amino-5bromopyrazin-3-thiol 8 as brownish ash powder. On the other hand, 4,6-diaminopyrimidine 9 was thiocyanated with sodium thiocyanate dihydrate in glacial acetic and bromine at $-5{ }^{\circ} \mathrm{C}$ to give 4,6 diamino-5-thiocyanatopyrimidine 10. Alkaline hydrolysis of 10 in $40 \% \mathrm{KOH}$ followed by neutralization with acetic acid gave 4,6diaminopyrimidine-5-thiol $\mathbf{1 1}$ (scheme 1).<smiles>Nc1cnccn1</smiles>

5

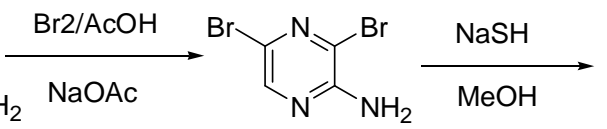

6<smiles>Nc1ncc(Br)nc1S(=O)(=O)[O-]</smiles>

7<smiles>Nc1ncc(Br)nc1S</smiles>
8<smiles>Nc1cc(N)ncn1</smiles>

9<smiles>NC(=O)C(=O)O</smiles><smiles>N#C[Si]c1c(N)ncnc1N</smiles>

10 (i) $\underset{\mathrm{KOH}}{\stackrel{\mathrm{AcOH}}{\longrightarrow}}$<smiles>Nc1ncnc(N)c1S</smiles>

11

Scheme 1:

When 4,5-diamino-6-hydroxypyimidine 12 was treated with 2,3-dichloro-1,4-naphthoquinone 13 in anhydrous sodium carbonate and benzene/ DMF, the concomitant product 11-amino-6chlorobenzo[a]-8,10-diazaphenoxazin-5-one 14 was obtained as a deep orange solid. Elemental analysis agrees with the molecular formular $\mathrm{C}_{14} \mathrm{H}_{7} \mathrm{~N}_{4} \mathrm{O}_{2} \mathrm{Cl}$. FT-Infrared spectrum gave bands at $3441,3344 \mathrm{~cm}^{-1}$ for $(\mathrm{N}-\mathrm{H})$ and at $1675 \mathrm{~cm}^{-1}$ for $(\mathrm{C}=\mathrm{O})$.
${ }^{1} \mathrm{H}$ and ${ }^{13} \mathrm{C}-\mathrm{NMR}$ provided further support for the assigned structure. The ${ }^{1} \mathrm{H}-\mathrm{NMR}$ could not resolve the individual protons but gave multiplet at ppm 7.807.70 due to aromatic protons while the singlet at 6.90 ppm was assigned to $\mathrm{NH}_{2} \cdot{ }^{13} \mathrm{C}-\mathrm{NMR}$ gave prominent chemical shift at ppm 191.3 for $\mathrm{C}=\mathrm{O}$ (scheme 2).

Formation of compound $\mathbf{1 4}$ is proposed as follows (Scheme 3). 
<smiles>Nc1ncnc(O)c1N</smiles>

12<smiles>O=C1C(Cl)=C(Cl)C(=O)c2ccccc21</smiles>

13



14

Scheme 2:<smiles>Nc1ncnc(O)c1N</smiles>

12<smiles>CC(C)=C1C(=O)c2ccccc2C(=O)C1=C(Cl)Cl</smiles>

13
$(-)$<smiles>Nc1ncnc(OC2C(=O)Nc3c(N)ncnc3C(=O)C2Cl)c1Cl</smiles>

16<smiles>[3H]N1c2c(N)ncnc2C(=O)C(Cl)=C2Oc3ccccc3C21O</smiles><smiles>Nc1ncnc2oc3c(Cl)c(=O)c4ccccc4c-3nc12</smiles>

14<smiles>CCO</smiles>

Structure 18 was assigned based on the

The presence of reactive halogen and carbonyl groups in compound $\mathbf{1 4}$ led to the consideration of further extension of the conjugated ring system. This was achieved by refluxing $11-$ amino-6-chlorobenzo[a]-8,10-diazaphenoxazin-5one 14 with 2-amino-5-bromopyrimidine-3-thiol 8 in a basic medium of anhydrous sodium carbonate for $11 \mathrm{~h}$ to furnish one of the tetraaza heterocycles 15-amino-8-bromo-6,9,12,14-tetraazabenzo[a] $[1,4]$ benzoxazino[3,2-c]phenothiazine 18 as an intense red powder $\mathrm{mp}>300^{\circ} \mathrm{C}$.<smiles>Nc1ncnc2oc3c(Cl)c(=O)c4ccccc4c-3nc12</smiles>

14<smiles>Nc1ncc(Br)nc1S</smiles>

8



16

Scheme 4: 


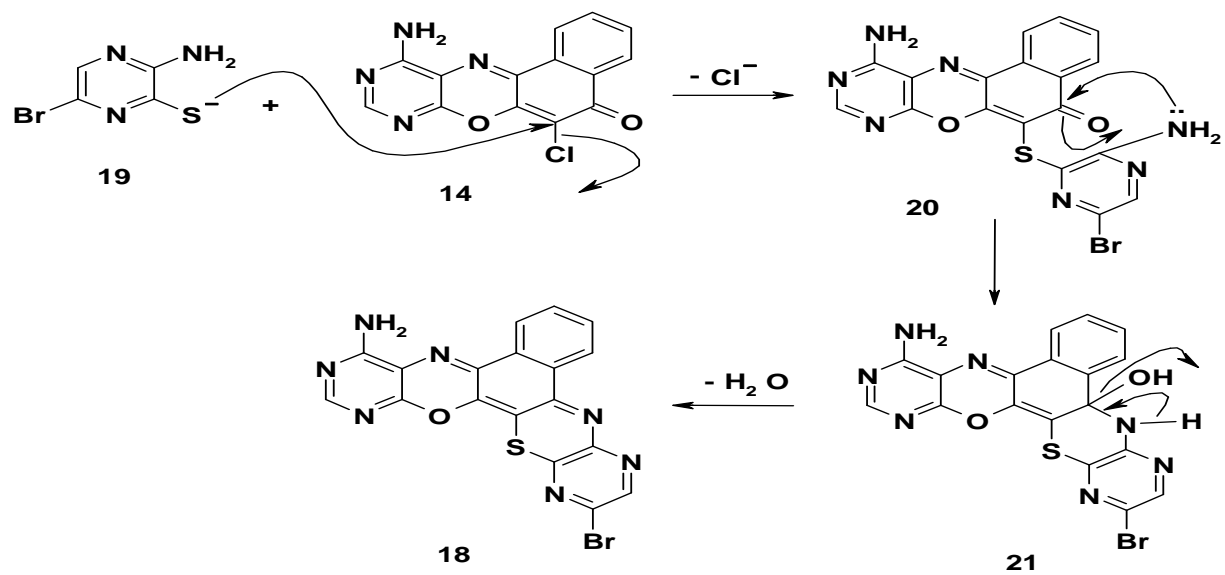

Scheme 5: Product 18 was likely formed by the proposed mechanism

When 11-amino-6-chlorobenzo[a]-8,10diazaphenoxazin-5-one 14 was also treated with 4,6-diaminopyrimidine-5-thiol 11 in anhydrous sodium carbonate, another tetraaza heterocycle 9,15-diamino-6,8,12,14-tetraazabenzo[a][1,4] benzoxazino[3,2-c]pheno- thiazine $22\left(\mathrm{R}=\mathrm{NH}_{2}\right)$ was obtained as reddish brown powder. The elemental analysis of $\mathbf{2 2}$ agreed with the molecular formular $\mathrm{C}_{18} \mathrm{H}_{10} \mathrm{~N}_{8} \mathrm{OS}$. ${ }^{1} \mathrm{H}$ and ${ }^{13} \mathrm{C}$ NMR gave further support for the assigned structure. Compound 22 exhibited proton chemical shifts signals in ppm as follows: 8.35 (s, H-7), 7.90-7.75 (m, H-1, H-2, H-3, $\mathrm{H}-4)$ and $6.79\left(2 \mathrm{NH}_{2}, \mathrm{br}\right)$.<smiles>Nc1ncnc2oc3c(Cl)c(=O)c4ccccc4c-3nc12</smiles>

14<smiles>[R]c1ncnc(N)c1[S-]</smiles>

11<smiles>[R]c1ncnc2c1sc1c3nc(nc4c(N)ncnc4oc12)-c1ccccc1-3</smiles>

22

$$
\mathbf{R}=\mathbf{N H}_{\mathbf{2}}, \mathbf{H}
$$

Scheme 6:

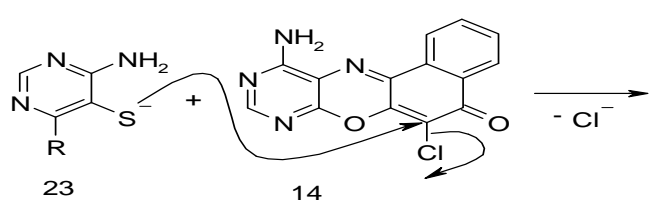<smiles></smiles>

22

$22 \mathrm{R}=\mathrm{NH}_{2}, \mathrm{H}$

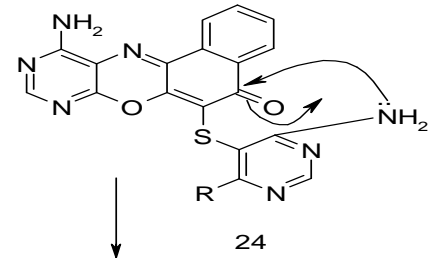



25

Scheme 7: Formation of 22 follows the proposed mechanism as in scheme 7 below 
Table 1. Fastness properties of synthesized heterocyclic dyes

\begin{tabular}{lcccccc}
\hline Dye no & $\begin{array}{c}\text { Wash } \\
\text { fastness }\end{array}$ & $\begin{array}{c}\text { Stain on undyed fabric } \\
\text { after washing (1-5) }\end{array}$ & $\begin{array}{c}\text { Sublimation } \\
\text { fastness (1-5) }\end{array}$ & \multicolumn{2}{c}{$\begin{array}{c}\text { Stain on undyed fabric } \\
\text { after sublimation (1-5) }\end{array}$} \\
\cline { 3 - 4 } & $(\mathbf{1 - 5 )}$ & Rayon & Cotton & & Rayon & Cotton \\
\hline 14 & 3 & 3 & $3-4$ & 3 & 3 & 4 \\
18 & 4 & 4 & $4-5$ & 4 & 4 & $4-5$ \\
$22\left(\mathrm{R}=\mathrm{NH}_{2}\right)$ & $4-5$ & 4 & $4-5$ & 4 & 4 & $4-5$ \\
$22(\mathrm{R}=\mathrm{H})$ & 4 & 4 & 5 & 4 & 4 & $4-5$ \\
\hline
\end{tabular}

Again, treatment of 14 with 4aminopyrimidin-5-thiol gave 15-amino-6,8,12,14tetraazabenzo[a][1,4]benzoxazino[3,2c]phenothiazine $22(\mathbf{R}=\mathbf{H})$ as dark purple brown powder: The elemental analysis of $\mathbf{2 2}(\mathrm{R}=\mathrm{H})$ agreed with the molecular formular $\mathrm{C}_{18} \mathrm{H}_{9} \mathrm{~N}_{7} \mathrm{OS} .{ }^{1} \mathrm{H}$ and ${ }^{13} \mathrm{C}$ NMR gave further support for the assigned structure. The compound 22 exhibited the following protons chemical shifts signals in ppm: 8.70 (s, H-7), 8.55 (s, H-9), 7.8-7.75 (m, H-1, H-2, H-3, H-4) and 6.50 $\left(\mathrm{NH}_{2}, \mathrm{~s}\right)$ (scheme 6).

Dyeing of nylon fabric with synthesized dyes:

The new compounds are vat dyes and they are applied in their reduced state. Dyeing was carried out in the presence of sodium dithionite and in aqueous solution of acetone/DMF/ acetic acid.
They exhibited good to excellent shades on the rayon fabric and showed excellent wash fastness and good sublimation fastness based on the international geometric gray standard (1 for poor and 5 for excellent respectively) as presented in the table.

\section{CONCLUSION}

Tetraaza heterocyclic compounds were synthesized and characterized by spectral and elemental analysis. Their ease of reduction with sodium hydrosulphide (sodium dithionite) makes them applicable as vat dyes. Their wash fastness, sublimation fastness and staining undyed fabric were evaluated.

\section{REFERENCES}

1. Shimamoto, T.; Tomoda, A.; Ishida, R.; Ohyashiki, K. Clin Cancer Res. 2001,7(3),704-708.

2. Horton, J. K.; Thimmaiah, K. N.; Harwood, F. C.; Kuttesch, J. F.; Houghton, P. J. Mol. Pharmacol. 1993, 44, 552-559.

3. Molnár, J; Mándi, Y; Király, J. Acta Microbio.I Acad. Sci. Hung. 1976, 23(1), 45-54.

4. Eregowda, G. B.; Kalpana, H. N.; Hegbe, R.; Thimmiah, K. N. Indian J. Chem. B, 2000, 39(4), 243-259.

5. Maas, H.; Khatyr, A.; Calzaferri, G. Microporus and mesoporus material, 2003, 65, 233-242.

6. Musha, S; Kitagawa, T; Nippo, K. Z. Chem. Abstract. 1957, 76.

7. Jenk, W.S. Advances in photochemistry. John Wiley \& Sons, Inc. Hokoken, 2002, 27, 1-50.
8. Kalkanidis, M.; Klonis, N.; Tilley, L.; Deady, L. W. Biochem Pharmacol, 2002, 63(5), 833

9. Korth, L. H. National Academy of Science, 2001, 17, 9836-9841.

10. Okafor, C. O.; Okerelu, I. O.; Okeke, S. I. Dyes and Pigments, 1987, 8, 11-24

11. Mitchell, S. C. Drug Metabolism. Rev., 1982, 13, 319-343.

12. Murphy, C. M.; Rarner, H.; Smith. N. L. Ind. Eng. Chem. 1950, 42, 2479

13. Agarwal, N. L.; Mital. R. L. Indian J. Chem.1976, 14, 381

14. Okafor, C. O. Tetrahedron, 1988, 44, 1187 1194.

15. Okafor, C. O. Journal of Heterocyclic Chemistry, 1980, 17, 1587-1592. 